\title{
Association of XmnI Polymorphism with Fetal Hemoglobin Level in Sudanese Patients with Sickle Cell Disease
}

\author{
Tarig Osman Khalafallah Ahmed ${ }^{1}$, Abeer Alshazaly Abdulrahman Altag² Ahmed Abdalla Agab Eldour ${ }^{3}$, \\ Anass M. Abbas ${ }^{4}$, Manar G.Shalabi ${ }^{4}$, Asaad Ma.Babker ${ }^{5}$ \\ ${ }^{1}$ Assistant Professor, Faculty of Medical Laboratory Science, Department of Hematology, University of Kordofan, \\ El-Obeid, Sudan, ${ }^{2}$ Scientist, Obeid Teaching Hospital, Ministry of Health, El-Obeid, Sudan, ${ }^{3}$ Professor, Faculty \\ of Medicine, Department of Pathology, University of Kordofan, El-Obeid, Sudan, ${ }^{4}$ Assistant professor, Clinical \\ Laboratory Sciences Department, College of Applied Medical Sciences- Jouf University, KSA, ${ }^{5}$ Associate \\ Professorof Hematology ,Department of Medical Laboratory Sciences, College of Health Sciences, Gulf Medical \\ University, Ajman, United Arab Emirates
}

\begin{abstract}
Background: Sickle cell disease (SCD) is an inherited blood disorder that affects red blood cells. The study of various modulating factors, and genetic factors affecting the clinical severity of the SCD is an interesting research focus especially in communities with a distinct genetic background. The XmnI polymorphism is a common genetic variation that was reported in previous studies to increase fetal hemoglobin $(\mathrm{HbF})$ level. This was a descriptive cross-sectional study, conducted in El-Obeid city in Northern Kordofan state, western Sudan, during the period from August to November 2016. The Xmn1 polymorphic site was determined by polymerase chain reaction. Data was analyzed using SPSS software program version 20. P-value of 0.05 and below was considered of significance. In present study $\mathrm{HbF}$ level among normal individuals AA, shown significant difference $(\mathrm{p}<0.05)$ between presence of $\mathrm{Xmnl}+/+$ and absence of Xmnl -/- site. in patients with $\mathrm{SS}$, the HbF level was higher in those who had one or two Xmnl sites as compared to those with the site absent . In patients with sickle cell trait AS and AA, only the presence of the one and two Xmnl site ( $+/+)$ compared to the absence of the site (-/-) was associated with significant increase in the HbF level. There is a close link between the Xmn1 polymorphism site and $\mathrm{HbF}$ level. A wide range of $\mathrm{HbF}$ level was obtained both in the present and absence of this site. Further studies with a large sample size as well as analysis BS haplotypes among the patient with sickle cell anemia population are needed for better understand of possible association .
\end{abstract}

Keywords: XmnI Polymorphism, SCD, Sickle cell disease, Fetal hemoglobin, HbF

\section{Introduction}

Sickle cell disease (SCD) is an inherited autosomal recessive disorder with presence of $\mathrm{Hb} \mathrm{S}$ in blood. This disease affects millions of peoples globally which results in serious complications due to vasoocclusive phenomenon and hemolysis. Sickle hemoglobin ( $\mathrm{Hb} \mathrm{S}$ ) is a structural variant of normal adult hemoglobin $(\mathrm{Hb}$ A) caused by a mutation in the HBB gene that leads to the substitution of valine for glutamic acid at position 6 of the $\beta$-globin's subunit ( $\beta S$ ) of the hemoglobin molecule $^{1}$. The pathological process in sickle cell disease is caused by the sickling phenomenon ${ }^{2}$.The basis of sickling in patients homozygous for the disorder, called sickle cell anemia or $\mathrm{Hb} \mathrm{SS}$, is polymerization of deoxy-Hb S resulting in the formation of multistranded fibers that create a gel and change the shape of RBCs from biconcave discs to elongated crescents. The polymerization/sickling reaction is reversible following reoxygenation of the hemoglobin. Thus, an RBC can undergo repeated cycles of sickling and un sickling ${ }^{3}$.The C-T substitution at position - 158 of the $\mathrm{Y}^{\mathrm{G}}$ globin gene referred to astheXmn1-y polymorphism is reported to be a common sequence variant inall population groups, present at a frequency of 0.32 to 0.35 . ${ }^{4}$.Clinical studies have shown that under conditions of hematopoietic stress, for example in homozygous B-thalassemia and sicklecell 
disease the presenceof the $\mathrm{Xmn} 1-\mathrm{Y}^{\mathrm{G}}$ site favors a higher $\mathrm{Hb} \mathrm{F}$ response This could explain why the same mutations on different $\mathrm{B}$ chromosomal backgrounds are associated with disease of different clinical severity ${ }^{5}$. The $\mathrm{y}^{\mathrm{G}}-158(\mathrm{C}-\mathrm{T})$ polymorphism plays important function in the disease severity of Sickle cell anemia. The $\mathrm{Xmn} 1$ restriction site at -158 position of the $\mathrm{y}^{\mathrm{G}}-$ gene isassociated with increased expression of the $\mathrm{y}^{\mathrm{G}}$ - goblin gene and higher production of $\mathrm{HbF}^{6}$.In Sudan several studies were conducted among patient with sickle cell disease $7,8,9$, but there are no studies to assess association between Xmn1 polymorphism and HbF level in sickle cell disease patient the prevalence in different area in Sudan. The aim of present study to association of XmnI polymorphism with fetal hemoglobin level in Sudanese patients with sickle cell disease.

\section{Material and Methods}

This was a descriptive cross-sectional study, conducted in El-Obeid city in Northern Kordofan state, western Sudan, during the period from August to November 2016. Known patients with sickle cell anemia attending Elobied children specialized hospital and Elkowity Hospital. Permission was taken from the committee of Kordofan university , El-Obeid Teaching Hospital and Elkowity Hospital, also consent was taking from patients and co-patients in Hospital.100 patient volunteer was selected using simple random technique. $2.5 \mathrm{ml}$ of venous blood was collected from each participant under complete antiseptic condition. Hemoglobin F was measured by modified Betke Method. The Xmn1 polymorphic site was determined by polymerase chain reaction. Data was analyzed using SPSS software program version 20. P-value of 0.05 and below was considered of significance.The sickle cell mutation was confirmed by amplifying the 5' region of the B. Globin genes followed by restriction digestion with Ddel A 650- bp fragment 5 'to the $\mathrm{YG}$ sense was amplified using the Primer5'AACTGTTFCTTTATAGGATTTT-3 and 5'AGGAGCTTATTGATAACCTCAGAC-3. The amplification condition were initial denaturation $94 \mathrm{c}$ for $5 \mathrm{~min}$ followed by 30 cycles of $94 \mathrm{c}$ for $1 \mathrm{~min}$ and $55 \mathrm{c}$ for $1 \mathrm{~min} 72 \mathrm{c} / \mathrm{min}$. with a final extension of $5 \mathrm{~min}$ at $72 \mathrm{c}$ the PCR product was digested with three unit of Xmn1 restriction enzyme and separated by electrophoresis on $3 \%$ agarose gel.

\section{Result}

Significantly different comparing Xmnl $+/+$ with Xmnl +/- $(\mathrm{p}<0.05)$ or comparing Xmnl +/+ with -/$(\mathrm{p}<0.05)$ in sickle cell patients $(\mathrm{SS})$, the $\mathrm{HbF}$ level was significantly higher in those who had two Xmnl sites $(p<0.05)$ compared to those with only one Xmnl site and with absent site $(p<0.05)$ in patients with SS who had one Xmnl site and Xmnl -/- site there is no difference in $\mathrm{HbF}$ level(Table I). .In AS patient's presence of two $\mathrm{Xmnl}+/+$ site compared with one Xmnl site $(\mathrm{p}<0.05)$ and one Xmnl site compared with Xmnl -/- site $(\mathrm{p}<0.05)$ had significant higher level of $\mathrm{HbF}$ (Table II). Significantly different comparing Xmnl +/- with Xmnl -/- $(\mathrm{p}<0.05)$ or comparing Xmnl $+/+$ with $+/-(\mathrm{p}<0.05)$ in normal control (AA), (Table III).

Table 1: The HbF percentage and Xmnl in SS group.

\begin{tabular}{|l|l|l|l|}
\hline Xmnl & SS(n=60) & HbF(mean \pm SD) & P.value \\
\hline$+/$ & $16(27 \%)$ & $81.97 \pm 3.30$ & $\mathrm{p}<0.05$ \\
\hline$+/$ & $20(33 \%)$ & $21.84 \pm 13.83$ & $\mathrm{p}<0.05$ \\
\hline$-/-$ & $24(40 \%)$ & $20.28 \pm 10.86$ & $\mathrm{p}<0.05$ \\
\hline
\end{tabular}


Table II: The association betweenHbF percentage and Xmnl in AS group.

\begin{tabular}{|l|l|l|l|}
\hline Xmnl & AS(n=30) & HbF(mean \pm SD) & P.value \\
\hline$+/+$ & $4(13 \%)$ & $17.45 \pm 0.58$ & $\mathrm{p}<0.05$ \\
\hline+- & $10(34 \%)$ & $0.8 \pm 0.57$ & $\mathrm{p}<0.05$ \\
\hline$-/-$ & $16(53 \%)$ & $0.04 \pm 0.11$ & $\mathrm{p}<0.05$ \\
\hline
\end{tabular}

Table III: The association between $\mathrm{HbF}$ percentage and $\mathrm{Xmnl}$ in AA group.

\begin{tabular}{|l|l|l|l|}
\hline Xmnl & AA(n=10) & HbF(mean \pm SD) & P.value \\
\hline$+/+$ & $2(20 \%)$ & $0.95 \pm 0.63$ & $\mathrm{p}<0.05$ \\
\hline$+/$ & $5(50 \%)$ & $0.37 \pm 0.22$ & $\mathrm{p}<0.05$ \\
\hline$-/-$ & $3(30 \%)$ & $0.02 \pm 0.08$ & $\mathrm{p}<0.05$ \\
\hline
\end{tabular}

\section{Discussion}

The XmnI polymorphism is a common genetic variation that was reported in previous studies to increase $\mathrm{HbF}$ level and therefore ameliorate the severity of the sickle cell disease. Our study shows that a polymorphism of the XmnI was found to be associated with higher expression of $\mathrm{HbF}$ in sickle cell and sickle cell trait patients. Several studies confirmed the association between XmnI and fetal hemoglobin ${ }^{10,11}$.Appositive association was observed between the HbF level and the presence of Xmn1 site in SS and sickle thalassemia groups Recently, other genetic association studies shown that several single nucleotide polymorphisms, associated with variation in the expression of $\mathrm{HbF}$ in sickle cell disease ${ }^{12}$.The $\mathrm{XmnI}$ polymorphism is known to influence the $\gamma^{\mathrm{G}}$ gene expression in sickle cell anemia and to increased $\mathrm{HbF}$ concentrations when they are under conditions of erythropoietic stress ${ }^{13}$. Study conducted by FarizKahhaleh et.al to assist the Association of Xmn1 polymorphism and consanguineous marriage with fetal hemoglobin in Syrian patients with sickle cell disease they concluded that a strong evidence on the importance of Xmn1 polymorphism and consanguineous marriage, among other factors, in the prediction of clinical severity and hydroxyurea response in SCD patients ${ }^{14}$. In sickle cell disease and sickle cell trait patients of Elobied, the presence of this polymorphism is associated with high $\mathrm{HbF}$ level. This is the first report of the frequency of the $-158 \mathrm{XmnI} \gamma^{\mathrm{G}}$-globin polymorphism in patients with SS and AS in Elobied.

\section{Conclusion}

There is a close link between the Xmn1 polymorphism site and $\mathrm{HbF}$ level. A wide range of $\mathrm{HbF}$ level was obtained both in the present and absence of this site. Further studies with a large sample size as well as analysis BS haplotypes among the patient with sickle cell anemia population are needed for better understand of possible association.

Acknowledgement: The authors are warmest thanks to all who participated in this study and especial thank to Elobied Teaching Hospital and Elkowity Hospital.

Conflict of Interest: All authors have none to declare

Ethical Clearance: Taken

Source of Funding: Self

\section{Reference}

1 Knar M, Dangi CBS, Singh M.An overview on sickle cell disease profile. Asian Journal of 
Pharmaceutical and Clinical Research.2013; 6(1):25-37.

2- Dean J, Schlecter AN. Sickle cell anemia, molecular and cellular basis of therapeutic approaches. New England Journal of Medicine.1978; 299:752-63.

3- Forget B.G, Bunn H.F. Classification of the disorders of hemoglobin. Cold Spring Harbor Perspectives in Medicine.2013;3(2):a011684.

4- Pissard S and Beuzard Y. A potential regulatory region for the expression of fetal hemoglobin in sickle cell disease. Blood. 1994.84:331-338.

5- Barbosa CG, Goncalves-Santos NJ, Souza-Ribeiro SB, Moura-Neto JP, Takahashi D, Silva DO, Hurtado-Guerrero AF, Reis MG, Gonçalves MD. Promoter region sequence differences in the $\mathrm{A}$ and G gamma globin genes of Brazilian sickle cell anemia patients. Brazilian journal of medical and biological research. 2010 ;43(8):705-11.

6- Bhagat, S., Patra, P.K. and Thakur, A.S.. Association between XmnI polymorphism and $\mathrm{HbF}$ level in sickle cell disease patients from Chhattisgarh. International journal of biomedical science.2012:8(1), p.36.

7- Mohamed, E.A., Elgari, M.M., Babker, A.M. and Waggiallah, H.A., . Comparative study of hypercoagulability change in steady state and during vaso-occlusive crisis among Sudanese patients living with sickle cell disease. African Health Sciences, 2020:20(1), pp.392-396.

8- Shireen, Z.N., Elshazali, W.A. and Hiba, K., Association of BCL11A Genetic Polymorphisms with Fetal haemoglobin Level in Sudanese Patients with Sickle Cell Anaemia. Journal Genomics \&
Gene Study.2019 2(1), p.2.

9- Sabahelzain, M.M. and Hamamy, H., 2014. The ethnic distribution of sickle cell disease in Sudan. Pan African medical Journal, 18(1).

10- Shimmoto MM, Vicari P, Fernandes AC, Guimarães GS, Figueiredo MS. XmnI polymorphism is associated with fetal hemoglobin levels in hypoplastic syndromes. Sao Paulo Med J. 2006 Mar 2;124(2):110-1. doi: 10.1590/s151631802006000200012 . PMID: 16878196.

11- Mannoor, K., Hossain, M., Noor, F.A., Bhuyan, G.S. and Qadri, S.S., 2019. Role of XmnI polymorphism in $\mathrm{HbF}$ induction in $\mathrm{HbE} / \beta$ and $\beta$-thalassaemia patients. Bangladesh Medical Research Council Bulletin, 45(3), pp.133-142.

12- Simpore J, Pignatelli S, Barlati S, Musumeci S. Modification in the frequency of $\mathrm{Hb} \mathrm{C}$ and $\mathrm{Hb} \mathrm{S}$ in Burkina Faso: an influence of migratory fluxes and improvement of patient health care. Hemoglobin. $2002 ; 26(2): 113-20$.

13- Bhagat S, Patra PK, Thakur AS. Association between XmnI Polymorphism and $\mathrm{HbF}$ Level in Sickle Cell Disease Patients from Chhattisgarh. International Journal of Biomedical Science. 2012 ;8(1):36-9.

14- Kahhaleh, F., Sulaiman, M. A., \&Alquobaili, F. (2019). Association of Xmn1 polymorphism and consanguineous marriage with fetal hemoglobin in Syrian patients with sickle cell disease. Cogent Medicine, 6(1), 1639243. https://doi.org/10.1080/2 $331205 X .2019 .1639243$. 